\title{
CULTIVATION OF GINSENG (PANAX GINSENG C. A. MEYER) IN BIOREACTOR: ROLE OF ETHYLENE ON CELL GROWTH AND GINSENOSIDES PRODUCTION
}

\author{
NGUYEN TRUNG THANH \\ National University of Hanoi, Vietnam \\ PAEK KEE YOEUP \\ Chungbuk Natinal University, South Korea
}

\begin{abstract}
Panax ginseng was cultivated in bioreactor under different concentrations of ethylene. The synthesis of saponin was greatly reduced in all the ethylene concentrations compared to control. The cell fresh $(320 \mathrm{~g} / \mathrm{L})$ and dry weight $(12.5 \mathrm{~g} / \mathrm{L})$ were increased at $10 \mathrm{ppm}$ ethylene concentration at the experiment end. However, at higher ethylene concentration $(20 \mathrm{ppm})$ the fresh and dry weight decreased significantly when compared with control. Ethylene shows a significant effect on sugar metabolism, which reduces the consumption of cations, anions and electrical conductivity (EC), where maximum accumulation of fresh and dry weight was occurred. By comparing with control, special oxygen uptake rate profile was almost unaffected by different concentrations of ethylene indicates that ethylene had no effect on cell respiratory metabolism. These results suggest that ethylene had stimulatory effect on fresh and dry weight production while inhibited saponin content.
\end{abstract}

Key words: ethylene, fresh weight, dry weight, cations, anions, saponin, sugar.

Panax ginseng is commonly known as red ginseng, which has most important bioactive compound known as saponin (a secondary metabolite named as ginsenosides). This compound has great importance in pharmaceutical industry because of its cardioprotective, immunomodulatory, antifatigue, anticancerous and anti-protective effects. More than 20 different kinds of ginsenosides have been identified from $P$. ginseng (Lee et al., 1995). The commercial sources of most gensenosides are mainly from roots.

The plant hormone ethylene is a signaling molecule involved in many plant metabolism processes and is essential for proper plant development, growth and survival. The exact role of ethylene is still unclear due to complex interaction between ethylene and other plant hormones and pathways. However, at low level, ethylene is beneficial to biomass production, growth while at higher level inhibited the all metabolic process as well as secondary metabolite production $[3,7]$.

Since all plants respond differently to stress, however, at least in part, ethylene level increased endogenously when plants exposed to different stress and increased damage has been documented [14]. Bioreactor technology is most difficult technology for the quick production of phytochemicals from tissue culture based techniques [6]. For large scale production of plants using bioreactor has been limited because of its high costs and associated abnormalities associated with cell morphology during long time cultivation [6]. For producing secondary metabolites with high value, plant cell cultures have several advantages. However, bioreactor study equipped with computer control systems offer theoretically various advantages of automation, low labour, low production costs and increase plant growth [6]. The main advantages using cell culture include faster growth rates, ability to grow in well-defined inexpensive media under controlled condition. Very few reports are available regarding effects of ethylene on cell growth and metabolite production in different species of Panax. The main aim of this study is to demonstrate the effects of ethylene on secondary metabolites 
production, cell growth, nutrients consumption, sugar metabolism in the cell culture of $P$. ginseng.

\section{MATERIALS AND METHODS}

\section{Subculture condition and induction of callus}

Fresh roots of mountain ginseng were collected from Korea and washed with a detergent solution for $8 \mathrm{~min}$ and then rinsed with running tap water for 8 min to remove the detergent. They were sterilized with $70 \%$ aqueous ethanol for $2 \mathrm{~min}$ under reduced pressure followed by $1 \%$ sodium hypochloride for $20 \mathrm{~min}$, and then rinsed repeatedly with sterile distilled water. The sterilized roots were cut into small sections $(2-10 \mathrm{~mm})$ and then were inoculated into MS solid medium supplemented with $30 \mathrm{~g} / \mathrm{l}$ sucrose, $1 \mathrm{mg} / \mathrm{l}$ 2,4-D and $0.1 \mathrm{mg} / \mathrm{l}$ kinetin. After 1 month of culture, induced calli were subcultured into above medium at an interval of three weeks for proliferation of callus. After 10 times of subculture into the solid medium, the calli were inoculated into liquid medium.

\section{Bioreactor culture and gas supply}

In this experiment, ginseng cell were treated with different concentrations of ethylene to determine the cell growth rate and saponin production. Various ethylene levels i.e., 5, 10 and $20 \mathrm{ppm}$ were supplied throughout the culture period in the air lift bioreactor. Sixty gram cell fresh weight/l were cultured for 30 days in a 5 liter balloon type air lift bioreactor containing 4 liter MS liquid medium supplemented with $7.0 \mathrm{mg} / \mathrm{l}$ IBA, $0.5 \mathrm{mg} / \mathrm{l}$ kinetin and $30 \mathrm{~g} / \mathrm{l}$ sucrose.

\section{Suspension culture and analyses}

The cells culture, determination of cell growth and development were as reported previous [9, 10, 11]. Extraction and determination of ginsenosides were done following modified methods of William et al. (1996). Total ginsenoside content was calculated as the sum of ginsenoside fractions and the ginsenoside content of ginseng cell were calculated as described in the previous study of William et al. (1996).

\section{Estimation of SOUR (special oxygen uptake rate)}

To determine the SOUR, $5 \mathrm{~g}$ cells (fresh weight) were added to $340 \mathrm{ml}$ chamber filled with air-saturated water and dissolved oxygen (DO) probe chamber was quickly inserted and closed with a rubber cap. The cells were kept in suspension by mixing with a magnetic stirring bar, and the decrease of DO level was recorded. Oxygen uptake rate (OUR) was estimated from DO slope against time, and SOUR was calculated from OUR and dry weight cell.

Measurement of electrical conductivity (EC), sugar content and determination of ion in medium were assayed HPLC with suppressed conductivity detector were reported by Thanh et al. (2006 a, b).

\section{RESULTS AND DISCUSSION}

\section{Kinetics of cell growth in a bioreactor}

Figure 1 shows, the time profiles of cell biomass growth under different concentrations of ethylene in $P$. ginseng. After 10 days of cultivation, the biomass accumulation rate became high and increased exponentially in all the ethylene concentrations including control plants. Maximum biomass accumulation was observed at $5 \mathrm{ppm}(8 \%)$ and $10 \mathrm{ppm}(11 \%)$ ethylene whereas higher ethylene (20 ppm) decreased the biomass accumulation significantly when compared with control value at the end of the experiment. Similarly, there was a significant difference in maximum dry weight production at different concentrations of ethylene. The maximum dry weight was recorded after 25 days of cultivation at $10 \mathrm{ppm}$ (16\%) ethylene followed by $5 \mathrm{ppm}(8 \%)$ compared to control (fig. 1B). Moreover, there was a large decrease in the dry weight at higher ethylene concentration (20 ppm) compared to control. This result suggests that ethylene had stimulatory and inhibitory effect on cell growth and biomass accumulation in bioreactor culture system. This inhibitory effect may be due to the presence of higher ethylene concentration in the medium and synthesis of endogenous ethylene that together affects the growth, development and other metabolic processes in the cultured cells. However, our result suggests that at low 
concentration, ethylene play an important role for growth of cells while at higher level, it usually produces adverse effect (Stearns and Glick, 2003). Similar results have been reported in cell culture of different species of Taxus [3]. The fresh to dry weight ratio (data not shown) was remained unchanged suggests that ethylene did not affected the morphology and cell size during cultivation time. However, previous workers reported decrease of FW to DW ratio in $P$. ginseng treated with jasmonates [6].

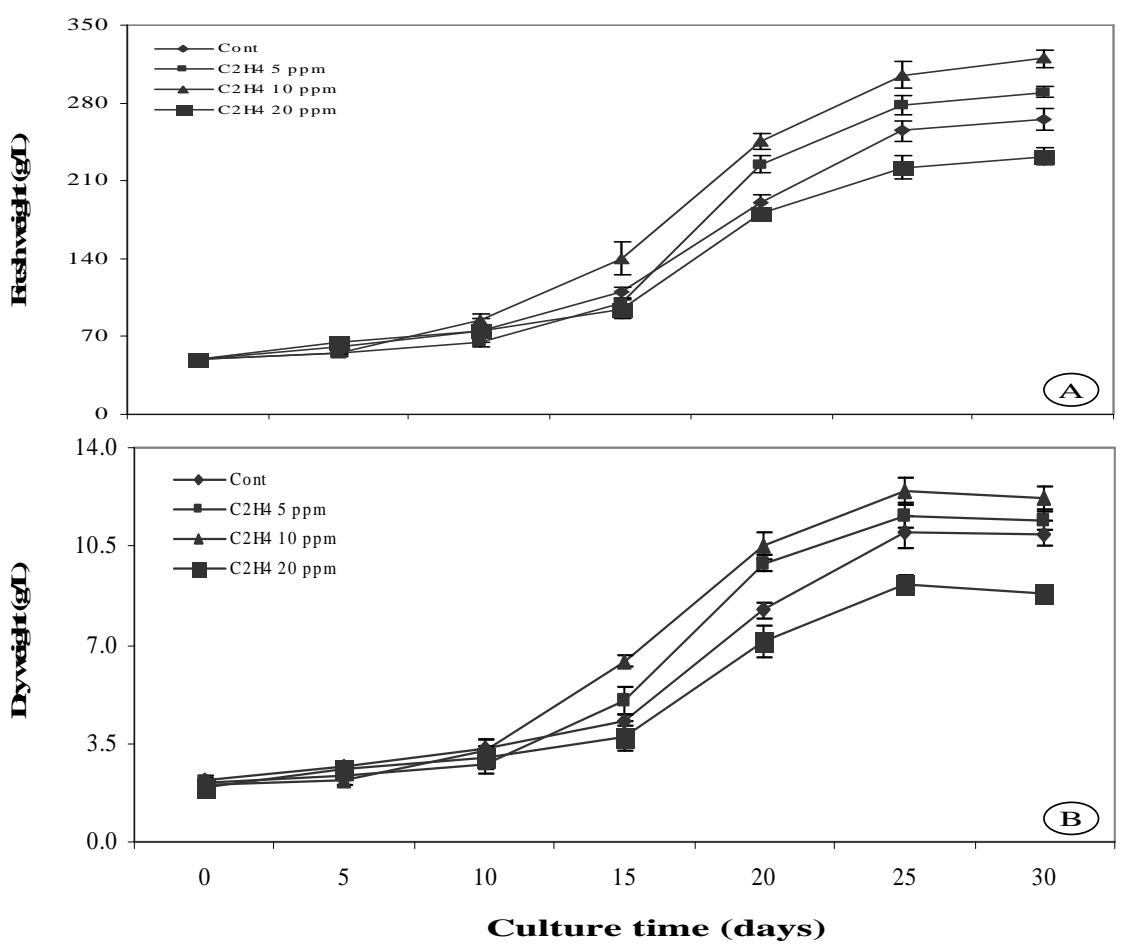

Figure 1. Growth kinetics of cell fresh weight (A) and dry weight (B) of $P$. ginseng in bioreactor culture under different $\mathrm{C}_{2} \mathrm{H}_{4}$ concentrations

2. Kinetics of gensenosides accumulation in cell suspension culture

Figure 2 shows, the dynamic profile of saponin content under different concentrations of ethylene in $P$. ginseng. It can be seen that yield of ginsenosides production was decreased significantly in all the ethylene concentrations compared to control. It suggests that ethylene can be effectively enough at the site of action to damage the main enzymes responsible for isoprenoid or phenylpropanoid pathway. However, phenylpropanoid pathway is enhanced by the ethylene and certain phenolic compounds have been associated with reductions and certain diseases [13]. The important thing is that ginsenosides content increased with progress of cultivation time even in the control plant and at $5 \mathrm{ppm}$ ethylene concentration. This small increase may be due to the induction of enzymes responsible for the synthesis of ginsenosides content caused by the dilution of suspension culture cells [4]. Similar results were reported in different plants under ethylene stress [7]. It shows that at higher concentration, ethylene have adverse effects on secondary metabolite production of cultured plant tissues and cells [3]. Recently, Zhang and Wu (2003) reported that ethylene inhibitors induces or stimulates the secondary metabolite production by inhibiting the mode action of ethylene production endogenously or supplied concentration in the medium. The mode of action of ethylene on growth and differentiation is highly variable and it is not yet clear why ethylene promotes growth, differentiation and secondary metabolite production in some case and inhibits them in other [13]. 


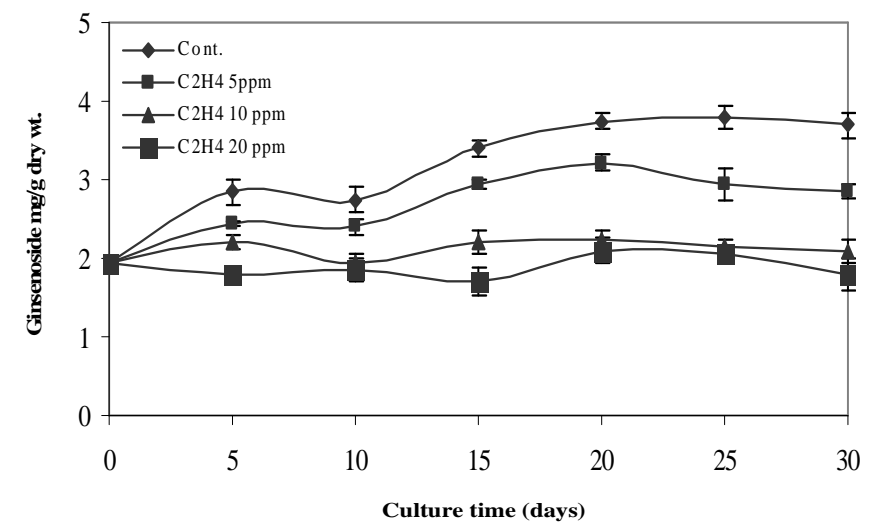

Figure 2. Time profile of ginsenoside accumulation by culture of $P$. ginseng cell in bioreactor under different $\mathrm{C}_{2} \mathrm{H}_{4}$ concentrations.

\section{Effect of ethylene on sugar content}

Figure 3 shows, the dynamic changes of sugar metabolism in the present investigation under different concentrations of ethylene. Data indicated that glucose was consumed almost completely when the cell reached their maximum respective growth peak under ethylene stress. However, at higher concentration $(20 \mathrm{ppm})$ sugar content remained higher in the medium than the control value. These results suggest that utilization of sugar increased the biomass at 5 and 10 ppm ethylene and inhibition of biomass at higher ethylene did not utilized the sugar and remained high in the medium. It seems that reduced biomass at higher ethylene concentration is direct inhibitory effect may be due to the programmed cell death [1].

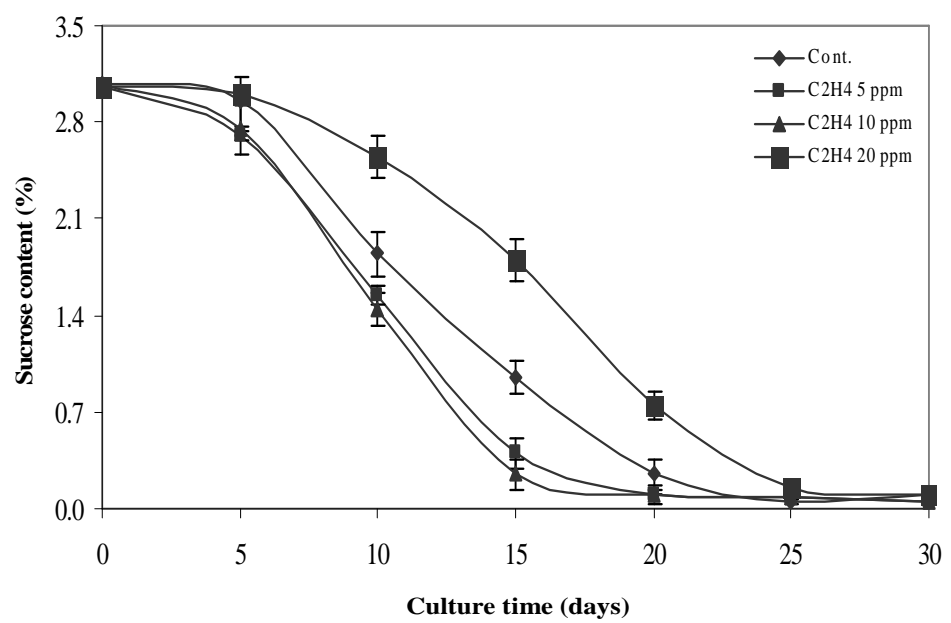

Figure 3. Changes in sugar contents in the exhausted media under different $\mathrm{C}_{2} \mathrm{H}_{4}$ concentrations

\section{Effect of ethylene on SOUR}

Figure 4 shows, the effect of ethylene on SOUR profile. The SOUR profile remained unchanged during the studied period. However, It was increased non-significantly after 10 days of cultivation and then decreased dramatically with the progress of cultivation time insignificantly when we compared with control. It indicates that ethylene had less influence on the cells respiratory activity in the present study. A similar result on SOUR profile has been reported [5]. The reduction of SOUR with control can be explained by the fact that reduced metabolic process may mitigate the effects of ethylene. 


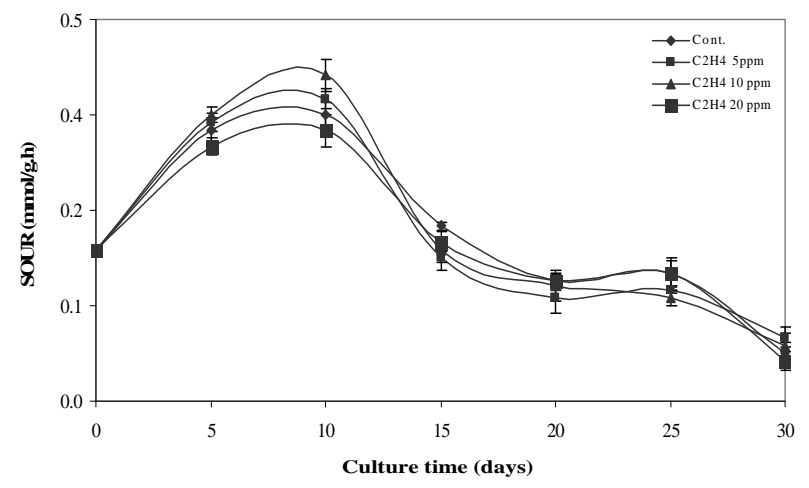

Figure 4. Time profiles of SOUR as affected by ethylene concentrations

\section{Effect of ethylene on nutrient consumption and EC level}

Cation and anion contents are presented in figure $5 \mathrm{~A}$ and $5 \mathrm{~B}$, respectively. Higher level of cations $\left(\mathrm{NH}_{4}^{+}, \mathrm{K}^{+}, \mathrm{Mg}^{2+}\right.$ and $\left.\mathrm{Ca}^{2+}\right)$ and anions $\left(\mathrm{NO}_{3}{ }^{-}, \mathrm{Cl}^{-}, \mathrm{PO}_{4}{ }^{2-}\right.$ and $\left.\mathrm{SO}_{4}{ }^{2-}\right)$ ions were observed at higher level of ethylene $(20 \mathrm{ppm})$ and minimum at $10 \mathrm{ppm}$ ethylene concentration compared to control. It indicates that cells growing in the higher medium did not accumulated cations and anions in the cells and remained in the medium. On the other hand, 5 and $10 \mathrm{ppm}$, these cations were decreased maximum showed maximum biomass bioaccumulation and taken up by the root cells. However, phosphate and sulphate anions were completely consumed in all the ethylene concentrations including control. It shows that the concentration at which had higher biomass profile consumed more ionic contents.
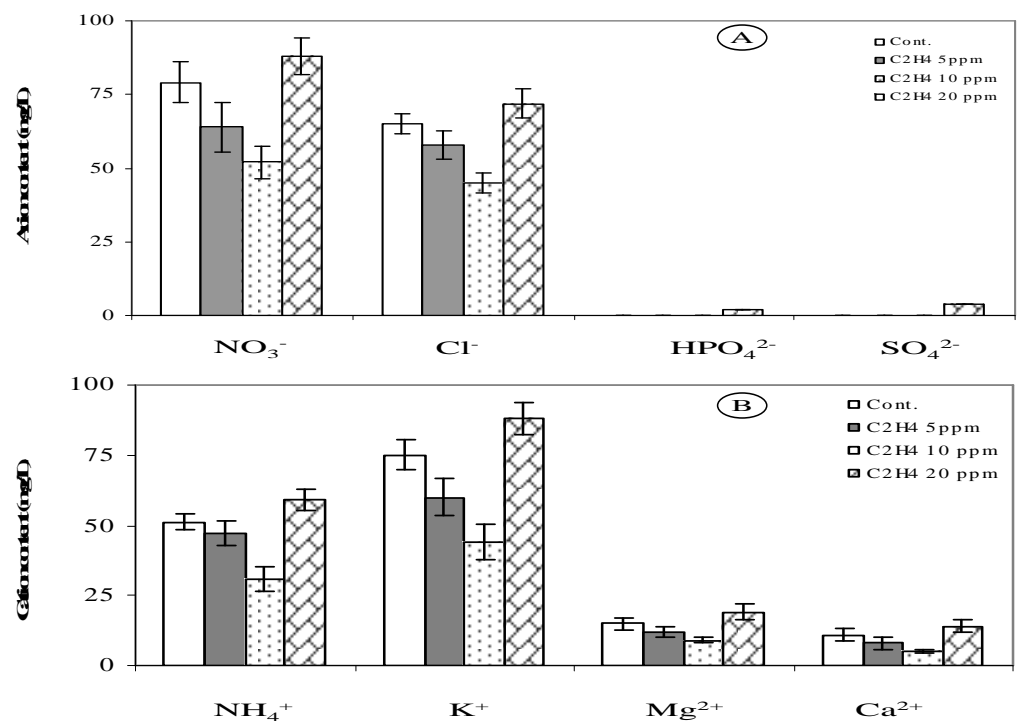

Figure 5. Changes of the mineral nutrients in the exhausted media (anions-A) and (cations-B) as affected by different ethylene concentrations

EC value was higher at higher ethylene concentration $(20 \mathrm{ppm})$ whereas it was inhibited at 5 and $10 \mathrm{ppm}$ ethylene compared to control (fig. 6). It indicates that cell grown at low concentration of ethylene had vigorous biomass 46 showed low level of EC implicates that cell consumed most of the nutrients supplied in the growth medium. In contrast, at higher level of ethylene, higher EC value was observed because of the less growth of the cell in this study. 


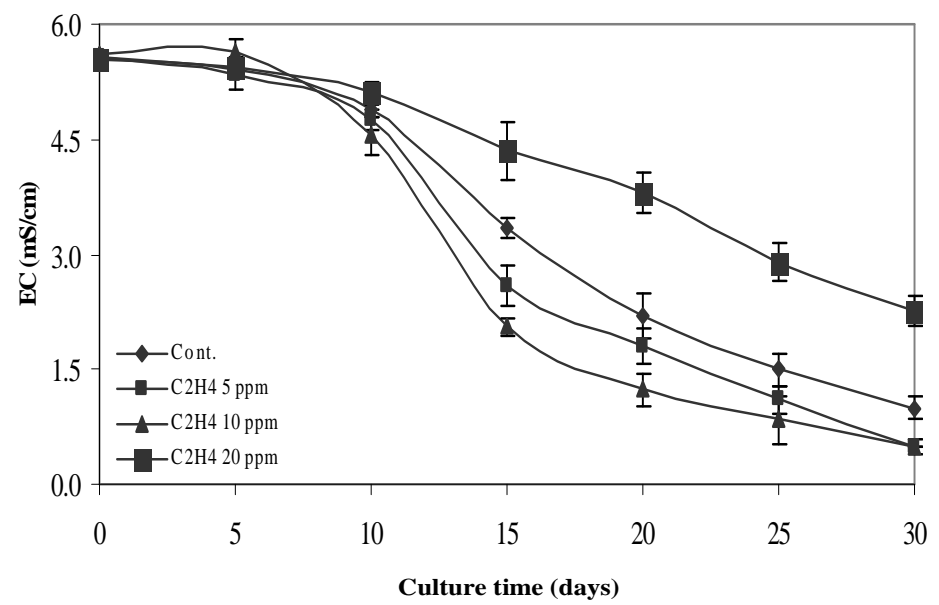

Figure 6. Changes of EC in the exhausted media as affected by ethylene concentrations

In conclusion, our findings regarding the negative effect of ethylene on ginsenosides production is the first report in the cell culture of $P$. ginseng in bioreactor culture system. Highest fresh and dry weight observed at 10 ppm ethylene compared to control. Consumption rate of nutrients were found higher where maximum biomass accumulation occurred. In contrast, SOUR profile was almost unaffected by ethylene incorporation. These results indicate that ethylene had stimulating effect on the cell growth and consumption of major nutrients.

\section{REFERENCES}

1. Johnson P. R. and J. R. Ecker, 1998: Annu. Rev. Genet., 32: 227-254.

2. Lee H. S., S. W. Kim, K.W. Lee, T. Eriksson and J. R. Liu, 1995: Plant Cell Rep., 14: 545-549.

3. Linden J. C., J. R. Haigh, N. Mirjalili and M. Phisaphalong, 2001: Adv. Biochem. Eng. Biotech., 72: 27-62.

4. Moreno P. R. H., H. C. P. R. Vander and R. Verpoorte, 1996: Enzyme and Microbial Technol., 18: 99-107.

5. Pan Z. W., H. Q. Wang and J. J. Zhong, 2000: Enzyme nad microbial tehnology, 27: 714-723.

6. Peak K. Y., E. J. Hahn and S. H. Son,
2001: In vitro Cell. Dev. Biol. Plant, 37: 149-157.

7. Pitta-Alvarez S. I., T.C. Spollansky and A. M. Giulietti, 2000: Enzyme Microb. Technol., 26: 252-258.

8. Thanh N. T., H. N. Murthy, Y. K. Woon, E. J. Hahn and P. K. Yoeup, 2004: J. Applied Microbiology Biotechnol, Netherlands, 67: 197-201.

9. Thanh N. T., M. B. Ali, Y. K. Woon, E. J. Hahn and P. K. Yoeup, 2005: J. Plant Science, Ireland, 169: 833-841.

10. Thanh N. T., H. N. Murthy, D. M. Pandey, Y. K. Woon, E. J. Hahn and P. K. Yoeup, 2006: J. Biologia Plantarum, Netherlands, 50(4): 752-754.

11. Thanh N. T., H. N. Murthy, Y. K. Woon, E. J. Hahn and P. K. Yoeup, 2006: Journal of Plant Physiology, Germany, 163: 13371341.

12. William A., G. John and J. Hendel, 1996: J. Chromatogr., 775: 11-17.

13. William L. P. and L. Y. Su, 2003. Ethylene and plant tissue culture. In: Matto A. K. and Suttle J. C. (eds.), The plant hormone, Ethylene. CRC Press, Boca Raton, Ann Arbor, Boston, London.

14. Zhang C. H. and J. Y. Wu, 2003: Enzyme and Microbial Technol., 32: 71-77. 


\title{
VAI TRÒ CỦA ETHYELENE TRONG QUÁ TRÌNH SINH TRƯởNG VÀ TÍCH LŨY SẢN PHẨM GINSENOSIDE TRONG QUÁ TRİNH NUÔI CẤY TẾ BÀO NHÂN SÂM (PANAX GINSENG C. A. MEYER) TRONG BIOREACTOR
}

\author{
NGUYỄN TRUNG THÀNH, PAEK KEE YOUEP
}

\begin{abstract}
TÓM TÁ́T
Tế bào Nhân sâm đã được nuôi cấy trong bioreactor và bổ sung ethylene trong quá trình nuôi cấy. Ethylene đóng vai trò rất quan trọng trong sự tăng sinh khối tế bào nhân sâm, ngược lại ethylene ức chế quá trình tổng hợp sản phẩm saponin ở nồng độ cao so sánh với đối chứng. Ở nồng độ $10 \mathrm{ppm}$ cho là ưu cho sự sinh trưởng và phát triển sinh khối tế bào $(320 \mathrm{~g} / \mathrm{L}$ trọng lượng tươi, $12,5 \mathrm{~g} / \mathrm{L}$ trọng lượng khô), hàm lượng ginsenosides là $(2,25 \mathrm{mg} / \mathrm{g}$ trọng lượng khô). Tiếp tục tăng nồng độ ethylene lên $20 \mathrm{ppm}$ sẽ làm giảm sinh khối tế bào cũng như hàm lượng saponin. Như vậy, khả tăng tạo sinh khối tế bào và sự tích lũy sản phẩm trao đổi chất ở đây tỷ lệ nghịch với nồng độ ethylene bổ sung vào môi trường nuôi cấy.

Ethylene cũng cho thấy có ảnh hưởng đối với tế bào nhân sâm khi hấp thu các cation, anion và $\mathrm{EC}$ trong môi trường nuôi cấy. Trong khi đó, SOUR thay đổi không đáng kể ở các nồng độ ethylene khác nhau, điều này cho thấy ethylene đã không ảnh hưởng đến sự hô hấp của tế bào trong quá trình nuôi cấy. Như vậy, kết quả này gợi ý rằng ethylene đóng vai trò trong sự tích lũy tế bào làm tăng sinh khối, nhưng ức chế quá trình tổng hợp ginsenoside ở nồng độ cao.
\end{abstract}

Ngày nhận bài: 2-3-2007 